\title{
Pengaruh Kemandirian Dan Gaya Belajar Terhadap Prestasi Belajar Matematika Siswa
}

\author{
Safniyati Ina Ola ${ }^{1)}$, Ridwan Idris ${ }^{2)}$, Baharuddin $^{3)}$ \\ 1,2,3 Fakultas Tarbiyah dan Keguruan UIN Alauddin Makassar \\ safniyati10@gmail.com ${ }^{1}$, ridwaidris11@yahoo.com $^{21}$, baharuddin.abbas@uin-alauddin.ac.id ${ }^{3)}$
}

\begin{abstract}
Abstrak
Jenis penelitian ini adalah penelitian kuantitatif dengan pendekatan ex-post facto. Populasi dalam penelitian ini adalah seluruh siswa kelas X SMA Negeri 3 Gowa dengan jumlah 245 siswa sedangkan sampelnya adalah 15\% dari seluruh siswa kelas X SMA Negeri 3 Gowa sebanyak 40 siswa yang diambil melalui teknik simple random sampling. Berdasarkan hasil analisis data menggunakan statistik deskriptif untuk kemandirian belajar diperoleh nilai rata-rata 56,40 berada pada kategori sedang dari 40 sampel diperoleh nilai terendah 40, nilai tertinggi 70, untuk gaya belajar diperoleh nilai rata-rata 51,05 berada pada kategori sedang dari 40 sampel diperoleh nilai terendah 30 , nilai tertinggi 63 , dan untuk prestasi belajar matematika diperoleh nilai rata-rata 77,62 berada pada kategori sedang dari 40 sampel diperoleh nilai terendah 75, nilai tertinggi 80. Dengan demikian dapat disimpulkan bahwa kemandirian belajar dan gaya belajar berpengaruh signifikan terhadap prestasi belajar matematika siswa.
\end{abstract}

Kata Kunci: Kemandirian, Gaya Belajar, Prestasi Belajar Matematika

\section{Pendahuluan}

Manusia adalah makhluk individu dan makhluk sosial. Dalam hubungannya dengan manusia sebagai makhluk sosial, terkandung suatu maksud bahwa manusia bagaimanapun juga tidak dapat terlepas dari individu yang lain. Secara kodrati manusia akan selalu hidup bersama. Dengan demikian kegiatan hidup manusia akan selalu dibarengi dengan proses interaksi atau komunikasi, baik interaksi dengan alam lingkungan, interaksi dengan sesamanya, maupun interaksi dengan Tuhannya, baik itu disengaja maupun tidak disengaja. Dari berbagai bentuk interaksi, khususnya mengenai interaksi yang disengaja, ada istilah interaksi edukatif. Interaksi edukatif ini adalah interaksi yang berlangsung dalam suatu ikatan untuk tujuan pendidikan dan pengajaran (Sardiman, 2003).

Pendidikan merupakan aktivitas sadar manusia dalam hubungan dengan manusia lain, terarah pada tujuan yang dikehendaki bersama, tanpa terlepas dari struktur sosial budaya tempat aktivitas tersebut berlangsung. Tujuan pendidikan sebagai subjek dan objek pendidikan, bagi masyarakat dengan nilai yang hidup dan berlaku di dalamnya, dan bagi negara sebagai pelaksana dan penanggung jawab pendidikan (Hamdani, 2011). Dalam sistem pendidikan yang demikian ini, siswa dituntut untuk memiliki kemandirian belajar. Kemandirian belajar merupakan kemampuan diri mengambil tanggung jawab belajarnya. Kemandirian belajar bukan berarti belajar seorang diri, tetapi belajar dengan inisiatif sendiri, dengan ataupun tanpa bantuan orang lain. Kemandirian belajar diartikan sebagai aktivitas belajar yang berlangsung lebih didorong oleh kemauan, pilihan, dan tanggung jawab sendiri dari siswa. Konsep kemandirian belajar bertumpu pada prinsip bahwa individu yang belajar akan sampai kepada perolehan hasil belajar (Nurhayati, 2011). Belajar mandiri adalah suatu proses, metode pendidikan dimana siswa dapat memperoleh pengetahuan dengan usaha sendiri. Selain kemandirian belajar, gaya belajar juga berpengaruh pada belajar siswa. Gaya belajar merupakan sebuah pendekatan yang menjelaskan mengenai bagaimana individu belajar atau cara yang ditempuh oleh masing-masing orang untuk berkonsentrasi pada proses, dan menguasai informasi yang sulit dan baru melalui persepsi yang beda. Gaya belajar bersifat individual bagi setiap orang. Dengan demikian, 
secara umum gaya belajar mengacu pada kepribadian-kepribadian, pilihan-pilihan, dan perilakuperilaku yang digunakan oleh individu untuk membantu dalam belajar mereka (Ghufron \& Risnawati, 2012).

Penelitian ini dilaksanakan di SMA Negeri 3 Gowa. Berdasarkan hasil wawancara yang dilakukan dengan salah seorang guru bidang studi matematika di SMA Negeri 3 Gowa diperoleh informasi bahwa masih ada siswa yang mendapatkan nilai dibawah kriteria ketuntasan minimum yaitu 75. Selain itu, dari guru bidang studi matematika juga diperoleh informasi mengenai siswa, baik dalam bentuk sikap maupun tindakannya seperti malas mengerjakan tugas atau siswa belajar jika dijanjikan akan diadakan kuis, mudah putus asa dalam menghadapi kesulitan, kurang aktif saat proses pembelajaran, kurang percaya diri dan terdapat siswa yang gelisah di kelas kemudian bertanya pada teman sebangkunya ketika guru memberi materi secara lisan, terdapat pula siswa yang meminta guru untuk menuliskan contoh soal dan jawabannya di papan tulis dan juga terdapat siswa yang diam saja tapi ketika ditanya guru, siswa tersebut tidak dapat menjawab masih banyak siswa yang mengalami kesulitan memahami pelajaran matematika yang mencerminkan kurangnya kemandirian belajar dan karakteristik belajar yang berbeda-beda pada siswa yang digunakan untuk menerima pelajaran merupakan gaya belajar mereka masing-masing.

Penelitian yang dilakukan oleh Pratistiya Nor Aini dan Abdullah Taman menunjukkan bahwa terdapat pengaruh positif dan signifikan kemandirian belajar dan lingkungan belajar siswa secara bersama-sama terhadap prestasi belajar akuntansi siswa kelas XI IPS SMA Negeri 1 Sewon Bantul (Aini \& Taman, 2012). Penelitian yang dilakukan Oleh Febti Rusmiyati menyimpulkan bahwa semakin tinggi kemandirian dan semakin baik kebiasaan belajar, maka semakin tinggi pula prestasi belajar matematika. Terdapat pengaruh yang positif dan signifikan antara kemandirian belajar dan kebiasaan belajar dengan prestasi belajar matematika siswa kelas X SMA Negeri 1 Rongkop tahun ajaran 2013/2014 (Rusmiyati, 2017). Sedangkan penelitian yang dilakukan oleh Dewi A.Sagitasari, mahasiswa FMIPA Universitas Negeri Yogyakarta menunjukkan bahwa terdapat hubungan yang positif dan signifikan antara kreativitas dan gaya belajar dengan prestasi siswa (Sagitasari, 2010).

Kemandirian belajar diartikan sebagai aktivitas belajar yang berlangsung lebih didorong oleh kemauan, pilihan, dan tanggung jawab sendiri dari pembelajaran. Konsep kemandirian belajar bertumpu pada prinsip bahwa individu yang belajar akan sampai kepada perolehan hasil belajar (Nurhayati, 2011). Menurut Kozma, Belle dan Williams, kemandirian belajar merupakan bentuk belajar yang memberi kesempatan kepada pembelajar untuk menentukan tujuan, sumber, dan kegiatan belajar sesuai dengan kebutuhan sendiri. Dalam proses belajar, pembelajar dapat berpartisipasi secara aktif menentukan apa yang akan dipelajari dan bagaimana cara mempelajarinya. Menurut Miarso kemandirian belajar adalah pengaturan program belajar yang diorganisasikan sedemikian rupa sehingga setiap pembelajar dapat memilih atau menentukan bahan dan kemajuan belajarnya sendiri. Wedmeyer menjelaskan, kemandirian belajar adalah cara belajar yang memberikan kebebasan, tanggung jawab, dan kewenangan yang lebih besar kepada pembelajar dalam merencanakan, melaksanakan, dan mengevaluasi kegiatan belajarnya (Yaumi, 2012). Kemandirian belajar adalah suatu proses, metode pendidikan dimana siswa dapat memperoleh pengetahuan dengan usaha sendiri, tanggung jawab, percaya diri, berinisiatif, memiliki motivasi yang kuat untuk maju demi kebaikan dirinya, mampu menyelesaikan masalah sendiri tidak menggantungkan diri kepada orang lain. 
James dan Gardner berpendapat bahwa gaya belajar adalah cara yang kompleks dimana para siswa menganggap dan merasa paling efektif dan efisien dalam memproses, menyimpan dan memanggil kembali apa yang telah mereka pelajari. Merriam dan Caffarella mendefenisikan gaya belajar yang populer di dalam pendidikan orang dewasa, yaitu karakteristik individu mengenai cara dalam memproses informasi, merasa, dan bertindak di dalam situasi-situasi, Reichman mengacu pada gaya belajar sebagai himpunan dari perilaku-perilaku dan sikap-sikap tertentu yang berhubungan dengan situasi belajar. Definisi Keefe mengenai gaya belajar adalah faktor-faktor kognitif, afektif, dan fisiologis yang menyajikan beberapa indikator yang relatif stabil tentang bagaimana para siswa merasa, berhubungan dengan lainnya dan bereaksi terhadap lingkungan belajar. Kolb mengatakan bahwa gaya belajar merupakan metode yang dimiliki individu untuk mendapatkan informasi, sehingga pada prinsipnya gaya belajar merupakan bagian integral dalam siklus belajar aktif (Ghufron \& Risnawati, 2012). Gaya belajar adalah sebuah pendekatan atau cara yang digunakan siswa dalam belajar yang menurutnya paling efektif digunakan, dalam memproses, menyimpan dan menggali ulang informasi yang telah didapat.

Prestasi belajar merupakan hasil yang didapat dengan baik pada seorang siswa baik dalam pendidikan atau bidang keilmuan. Siswa memperoleh prestasi belajar dari hasil yang telah dicapai dari proses belajar. Prestasi belajar merupakan hasil pencapaian yang maksimal menurut kemampuan siswa pada waktu tertentu pada sesuatu yang dipelajari, dikerjakan, dimengerti dan diterapkan (Mustamin \& Sulasteri, 2013). Prestasi belajar diartikan sebagai tingkat keterkaitan siswa dalam proses belajar mengajar sebagai hasil evaluasi yang dilakukan guru. Prestasi belajar juga bisa disebut sebagai hasil belajar. Hasil belajar adalah kemampuan-kemampuan yang dimiliki siswa setelah ia menerima pengalamannya (Sudjana, 2003).

Hasil belajar adalah keseluruhan kegiatan pengukuran (pengumpulan data dan informasi), pengolahan, penafsiran dan pertimbangan untuk membuat keputusan tentang tingkat hasil belajar yang dicapai oleh siswa setelah melakukan kegiatan belajar dalam upaya mencapai tujuan pembelajaran yang telah ditetapkan. Hasil belajar menunjukan pada prestasi belajar, sedangkan prestasi belajar itu merupakan indikator adanya derajat perubahan tingkah laku siswa (Hamalik, 2005). Prestasi belajar memiliki posisi penting dalam pendidikan, karena sebagai tolak ukur keberhasilan proses pembelajaran, sekaligus sebagai bahan evaluasi bagi para pelaku pendidikan. Atau dapat dirumuskan sebagai: 1) indikator kualitas dan kuantitas materi pelajaran yang telah dikuasai siswa, 2) lambang hasrat ingin tahu 3) inovasi dan pendorong bagi peningkatan ilmu pengetahuan dan teknologi, sekaligus berperan sebagai umpan balik bagi peningkatan mutu pendidikan (Qodriyah, 2011).

\section{Metodologi Penelitian}

Jenis penelitian yang digunakan termasuk penelitian kuantitatif. Penelitian ini menggunakan metode ex post facto karena peneliti tidak memberikan perlakuan atau memanipulasi perubahan khusus terhadap subjek penelitian (Sukardi, 2003). Desain penelitian yang digunakan yaitu paradigma ganda, dimana dalam penelitian terdapat dua variabel independen dan satu variabel dependen. Populasi dalam penelitian ini adalah seluruh siswa kelas X SMA Negeri 3 Gowa Kab. Gowa yang berjumlah 245 siswa yang terdiri dari 7 kelas. Dalam penelitian ini peneliti mengambil sampel yaitu sebanyak 40 siswa.

Adapun teknik Pengambilan sampel dalam penelitian ini adalah probability sampling yaitu simple random sampling. Pengambilan sampel merujuk pada pendapat Arikunto yang menyatakan 
jika anggota populasi kurang dari 100 maka semua populasi diambil sebagai sampel, akan tetapi jika jumlah subjeknya besar, dapat diambil antara $10-15 \%$ atau $20-25 \%$ atau lebih, tergantung setidaktidaknya kemampuan peneliti, sempit luasnya wilayah pengamatan dari setiap subjek dan besar kecilnya resiko yang ditanggung peneliti. Dalam penelitian ini peneliti mengambil sampel $15 \%$ yaitu sebanyak 40 siswa. Berdasarkan uraian tersebut maka yang menjadi subyek populasi dalam penelitian ini yakni seluruh siswa kelas X SMA Negeri 3 Gowa Kab. Gowa yang berjumlah 245 siswa yang terdiri dari 7 kelas yaitu kelas $\mathrm{X}_{1}, \mathrm{X}_{2}, \mathrm{X}_{3}, \mathrm{X}_{4}, \mathrm{X}_{5}, \mathrm{X}_{6}, \mathrm{X}_{7}$.

Instrumen yang digunakan peneliti untuk mengumpulkan data dalam penelitian ini adalah dengan menggunakan skala kemandirian belajar dan skala gaya belajar. Penentuan jenis pilihan jawaban dari skala yang digunakan yaitu dengan menggunakan skala likert melalui lima kategori jawaban. Sugiono menjelaskan bahwa skala likert merupakan metode pengukuran yang digunakan untuk mengukursikap, pendapat dan persepsi seseorang tentang fenomena sosial.

Teknik analisis data yang digunakan dalam penelitian ini adalah analisis statistik, dimana ada tiga variabel yang akan diuji yaitu kemandirian belajar (X1), gaya belajar (X2), dan prestasi belajar matematika sebagai variabel (Y). Berdasarkan rumusan masalah yang diuraikan di atas maka pengolahan data hasil penelitian menggunakan analisis statistik deskriptif dan analisis statistik inferensial. Statistik deskriptif adalah statistik yang digunakan untuk menganalisis data dengan cara mendeskripsikan atau menggambarkan data yang telah terkumpul sebagaimana adanya tanpa bermaksud membuat kesimpulan yang berlaku utuk umum. Statistik inferensial adalah teknik analisis data yang digunakan untuk menganalisis data sampel dan hasilnya diberlakukan untuk populasi. Statistik inferensial digunakan untuk menguji hipotesis penelitian yang diajukan. Sebelum melakukan pengujian hipotesis, dilakukan uji prasyarat.

\section{Hasil}

Hasil penelitian ini adalah jawaban atas rumusah masalah yang telah ditetapkan. Rumusan masalah dijawab dengan menggunakan analisis deskriptif dan analisis inferensial.

Berikut tabel kategorisasi terhadap skor skala kemandirian belajar dengan tingkat kategori rendah, sedang, dan tinggi.

Tabel 1. Persentase Kemandirian Belajar Siswa Kelas X di SMA Negeri 3 Gowa

\begin{tabular}{cccc}
\hline Interval & Frekuensi & Persentase & Kategori \\
\hline $\mathrm{x}<50$ & 7 & $17,, 5 \%$ & Rendah \\
$50 \leq \mathrm{x}<60$ & 19 & $47,50 \%$ & Sedang \\
$\mathrm{x}>60$ & 14 & $35 \%$ & Tinggi \\
\hline Jumlah & 40 & $100 \%$ & \\
\hline
\end{tabular}

Berdasarkan tabel 1 di atas, dapat disimpulkan bahwa skor kemandirian belajar pada seluruh subjek penelitian ini termasuk kategori sedang yang berarti bahwa pencapaian indikator untuk skala kemandirian belajar dalam hal ini indikator percaya diri, disiplin, inisiatif dan tanggung jawab dalam pembelajaran matematika belum seluruhnya terpenuhi. Hal tersebut dilihat dari rendahnya data yang diperoleh dari pengisisan angket siswa untuk indikator tanggung jawab dalam proses pembelajaran. 
Tabel 2. Persentase Gaya Belajar Siswa Kelas X di SMA Negeri 3 Gowa

\begin{tabular}{cccc}
\hline Interval & Frekuensi & Persentase & Kategori \\
\hline $\mathrm{x}<41$ & 5 & $12,50 \%$ & Rendah \\
$41 \leq \mathrm{x}<52$ & 22 & $55,00 \%$ & Sedang \\
$\mathrm{x}>52$ & 13 & $33 \%$ & Tinggi \\
\hline Jumlah & 40 & $100 \%$ & \\
\hline
\end{tabular}

Berdasarkan tabel 2 di atas, dapat disimpulkan bahwa skor gaya belajar pada seluruh subjek penelitian ini termasuk kategori sedang yang berarti bahwa pencapaian indikator untuk skala gaya belajar dalam hal ini indikator belum seluruhnya terpenuhi. Hal tersebut dilihat dari rendahnya data yang diperoleh dari pengisisan angket siswa untuk indikator tanggung jawab dalam proses pembelajaran.

Tabel 3. Persentase Prestasi Belajar Matematika Siswa Kelas X SMA Negeri 3 Gowa

\begin{tabular}{cccc}
\hline Interval & Frekuensi & Persentase & Kategori \\
\hline $\mathrm{x}<76,6$ & 9 & $22,50 \%$ & Rendah \\
$76,6 \leq \mathrm{x}<78$ & 17 & $42,50 \%$ & Sedang \\
$\mathrm{X}>78$ & 14 & $35 \%$ & Tinggi \\
\hline Jumlah & 40 & $100 \%$ & \\
\hline
\end{tabular}

Berdasarkan tabel 3 di atas, dapat disimpulkan bahwa skor prestasi belajar matematika pada seluruh subjek penelitian ini termasuk kategori sedang yang berarti bahwa kecenderungan kemampuan siswa masih berada di bawah hasil maksimal yang diharapkan akan tetapi telah memenuhi nilai KKM yang telah ditetapkan oleh sekolah. Hal tersebut dapat dilihat dari data nilai prestasi belajar yang diperoleh siswa setelah ujian tengah semester yang rata-rata berada pada nilai 76-78 dari nilai KKM yaitu 75 dan nilai maksimal yaitu 100.

Tabel 4. Uji Linearitas Kemandirian Belajar terhadap Prestasi Belajar Matematika

\begin{tabular}{llccccc}
\hline & & Sum & df & Mean Square & F & Sig. \\
\hline Prestasi Belajar* & Between (Combined) & 59,458 & 19 & 3,129 & 1,045 &, 461 \\
Kemandirian Belajar & Groups Linearity &, 441 & 1 &, 441 &, 147 &, 705 \\
& \multicolumn{1}{c}{ Deviation } & 59,017 & 18 & 3,279 & 1,094 &, 420 \\
& Within Groups & 59,917 & 20 & 2,996 & & \\
\hline & Total & 119,375 & 39 & & & \\
\hline
\end{tabular}

Tabel 4 di atas menunjukan bahwa hasil uji linearitas kemandirian belajar terhadap prestasi belajar matematika diperoleh hasil sig $0,420>\alpha(0,05)$ berarti data kemandirian belajar linear.

Tabel 5. Uji Linearitas Gaya Belajar terhadap Prestasi Belajar Matematika

\begin{tabular}{|c|c|c|c|c|c|c|}
\hline & & Sum & $d f$ & Mean & $\boldsymbol{F}$ & Sig. \\
\hline Prestasi Belajar * & (Combined) & 63,008 & 18 & 3,500 & 1,304 & 278 \\
\hline \multirow[t]{4}{*}{ Gaya Belajar } & Linearity & 8,614 & 1 & 8,614 & 3,209 & ,088 \\
\hline & Deviation & 54,394 & 17 & 3,200 & 1,192 & 347 \\
\hline & Within Groups & 56,367 & 21 & 2,684 & & \\
\hline & Total & 119,375 & 39 & & & \\
\hline
\end{tabular}


Berdasarkan tabel 5 di atas uji liniearitas gaya belajar terhadap prestasi belajar matematika diperoleh hasil sig $0,347>\alpha(0,05)$ sehingga data gaya belajar linear.

Tabel 6. Hasil Analisis Regresi Linier Berganda

\begin{tabular}{llccccc}
\hline \multirow{2}{*}{ Model } & \multicolumn{3}{c}{ Unstandardized Coefficients } & Standardized Coefficients & \multirow{2}{*}{ t } & \multirow{2}{*}{ Sig. } \\
\cline { 2 - 5 } & $\mathrm{B}$ & Std. Error & Beta & & \\
\hline 1 & (Constant) & 72,584 & 3,232 & & 22,459 &, 000 \\
& Kemandirian Belajar &, 018 &, 037 &, 076 &, 482 &, 633 \\
& GayaBelajar &, 079 &, 046 &, 273 & 1,726 &, 093 \\
\hline
\end{tabular}

Dari tabel 6 menunjukan bahwa model persamaan regresi berganda untuk memperkirakan prestasi belajar matematika yang dipengaruhi oleh kemandirian belajar dan gaya belajar adalah:

$$
\hat{Y}=72,584+0,018 X_{1}+0,079 X_{2}
$$

Dari persamaan di atas, dapat diketahui bahwa semakin besar kemandirian belajar dan gaya belajar maka variabel prestasi belajar matematika siswa juga semakin besar. Koefisien regresi berganda sebesar 0,018 dan 0,079 mengindikasikan bahwa besaran penambahan tingkat prestasi belajar matematika setiap pertambahan jawaban siswa untuk variabel kemandirian belajar dan prestasi belajar. Berdasarkan aplikasi analisis SPSS 22 diperoleh kesimpulan hasil analisis yaitu sebagai berikut:

Tabel 7. Uji Signifikansi Koefisien Regresi Ganda

\begin{tabular}{cccccc}
\hline Regresi & $\mathbf{R}$ & $\mathbf{R}^{2}$ & $\mathbf{F}$ & Sig & Kesimpulan \\
\hline $\mathrm{X}_{1} \mathrm{X}_{2} \mathrm{Y}$ & 0,279 & 0,78 & 1,564 & 0,000 & Berkorelasi Positif Sangat Signifikan \\
\hline
\end{tabular}

Berdasarkan hasil analisis diperoleh nilai $\mathrm{R}_{\mathrm{xy}}$ sebesar 0,279. Hal ini menunjukan bahwa terjadi pengaruh yang cukup erat antara kemandirian belajar dan gaya belajar terhadap prestasi belajar matematika. Dari hasil analisis data yang dilakukan dapat disimpulkan bahwa terdapat pengaruh yang signifikan $($ sig $<0,05)$ antara kemandirian belajar dan gaya belajar terhadap prestasi belajar matematika siswa kelas X SMA Negeri 3 Gowa.

\section{Pembahasan}

Berdasarkan hasil analisis inferensial data yakni uji prasyarat dan uji regresi ganda yang telah dilakukan, diketahui bahwa hasiil uji normalitas pada variabel kemandirian belajar menunjukkan nilai signifikan sebaesar 0,200 > 0,05 yang berarti bahwa sebaran atau distribusi data normal, dalam uji linieritas kemandirian belajar terhadap prestasi belajar matematika diperoleh hasil signifikan sebesar 0,420 dengan taraf signifikan sebesar 0,05 karena signifikan 0,420>0,05, maka hubungan antara kemandirian belajar dan prestasi belajar adalah linear. Sedangkan pada variabel gaya belajar diketahui bahwa hasil uji normalitas pada variabel gaya belajar menunjukkan nilai signifikan sebesar 0,066 > 0,05 yang berarti bahwa sebaran atau distribusi data normal, dalam uji linieritas gaya belajar terhadap prestasi belajar matematika diperoleh hasil signifikan 0,347 dengan taraf signifikan sebesar 0,05 
karena signifikansi 0,347 >0,05, maka terdapat hubungan antara gaya belajar dan presentasi belajar matematika siswa.

Dengan adanya kemandirian dan gaya belajar akan mempengaruhi prestasi belajar siswa. Jika kemandirian dan gaya belajar cukup baik maka siswa akan ada kemauan untuk selalu belajar dan fokus memperhatikan materi pelajaran, sehingga tujuan pembelajaran dapat tercapai dan hasil belajarnya akan cukup baik. Hal tersebut dapat dilihat dari hasil sig. regresi linear berganda, dimana kemandirian belajar sebesar 0,633 sedangkan gaya belajar sebesar 0,093. Namun secara keseluruhan kedua variabel tersebut sama-sama memberi pengaruh yang cukup baik terhadap prestasi belajar matematika siswa.

\section{Kesimpulan}

Berdasarkan hasil penelitian dan pembahasan, maka dapat ditarik kesimpulan yakni 1) kemandirian belajar matematika siswa kelas X SMA Negeri 3 Gowa berada pada kategori sedang yang berarti bahwa pencapaian indikator untuk skala kemandirian belajar belum terpenuhi secara maksimal namun telah berada di atas batas kategori terendah. Hal tersebut dapat dilihat dari rendahnya data yang diperoleh dari pengisian angket siswa, 2) gaya belajar siswa kelas X SMA Negeri 3 Gowa berada pada kategori sedang yang berarti bahwa pencapaian indikator gaya belajar belum seluruhnya terpenuhi, 3) prestasi belajar matematika siswa kelas X SMA Negeri 3 Gowa berada pada kategori sedang yang berarti bahwa kecenderungan kemampuan siswa masih berada di bawah hasil maksimal yang diharapkan akan tetapi telah memenuhi nilai KKM yang telah ditetapkan oleh sekolah, 4) berdasarkan hasil analisis statistik inferensial kemandirian belajar terhadap prestasi belajar matematika siswa kelas X SMA Negeri 3 Gowa diperoleh bahwa pengaruh kemandirian belajar terhadap prestasi belajar siswa dengan nilai signifikansi sebesar 0,710 artinya memberi pengaruh positif, 5) berdasarkan hasil analisis statistik inferensial gaya belajar terhadap prestasi belajar matematika siswa kelas X SMA Negeri 3 Gowa diperoleh bahwa pengaruh gaya belajar terhadap prestasi belajar siswa dengan nilai signifikansi sebesar 0,093 artinya memberi pengaruh positif, 6) berdasarkan hasil analisis statistik inferensial secara bersama-sama kemandirian belajar dan gaya belajar terhadap prestasi belajar matematika siswa kelas X SMA Negeri 3 Gowa. Sumbangsi pengaruh variabel kemandirian belajar dan gaya belajar sebesar 78\% sedangkan selebihnya dipengaruhi oleh variabel lain yang tidak dimasukan dalam penelitian ini.

\section{Daftar Pustaka}

Aini, P. N., \& Taman, A. (2012). Pengaruh Kemandirian Belajar dan Lingkungan Belajar Siswa Terhadap Prestasi Belajar Akuntansi Siswa Kelas XI IPS SMA Negeri 1 Sewon Bantul Tahun Ajaran 2010/2011. Jurnal Pendidikan Akuntansi Indonesia, 10(1), 48-49.

Ghufron, N., \& Risnawati, R. (2012). Gaya Belajar. Celeben Timur: Pustaka Pelajar.

Hamalik, O. (2005). Kurikulum dan Pembelajaran. Jakarta: PT Bumi Aksara.

Hamdani. (2011). Dasar-Dasar Kependidikan. Bandung: Pustaka Setia.

Mustamin, H., \& Sulasteri, S. (2013). Faktor-Faktor yang Mempengaruhi Prestasi Belajar Mahasiswa Jurusan Pendidikan Matematika Fakultas Tarbiyah dan Keguruan UIN Aluddin Makassar. Jurnal Matematika Dan Pembelajaran, 1(1).

Nurhayati, E. (2011). Psikologi Pendidikan Inovatif. Celeban Timur: Pustaka Pelajar.

Qodriyah, A. (2011). Hubungan Antara Gaya Belajar dengan Hasil Belajar Mata Pelajaran Aqidah Akhlak Siswa Kelas IV MI Miftakhul Akhlaqiyah Bringin Ngaliyan Semarang. Institut Agama Islam Walisongo Semarang. 
Rusmiyati, F. (2017). No Title. Jurnal Pendidikan Matematika, 5(1), 82.

Sagitasari, D. A. (2010). Hubungan Antara Kreativitas dan Gaya Belajar dengan Prestasi Belajar Matematika Siswa SMP. Universitas Negeri Yogyakarta.

Sudjana, N. (2003). Penilaian Hasil Belajar Mengajar. Jakarta: Remaja Rosdakarya.

Sukardi. (2003). Metodologi Penelitian Kompetensi dan Praktik (Cet. VII). Jakarta: Bumi Aksara.

Yaumi, M. (2012). Pembelajaran Berbasis Multiple Intelligence. Jakarta: PT. Dian Rakyat. 